\title{
Gustaf Retzius - a glimpse into his lifetime achievements and into the fabric of his character
}

\author{
M. Gazi Yaşargil, Dianne C. H. Yaşargil \\ Department of Neurosurgery, School of Medicine, Yeditepe University, Istanbul, Turkey
}

\begin{abstract}
Magnus Gustaf Retzius, 1842-1919, was a prolific researcher, honored and respected at home and abroad during his lifetime. His achievements are many and varied. He established pivotal and essential foundations in human anatomy and natural sciences on which, even today, research, teaching, medicine and surgery are founded. He paved the way for future scientists to advance and progress in these fields. The precise portrayal and superb presentation of his studies bear witness to a man obsessed with revealing the absolute reality. The text of all his anatomic publications is in German. Regretfully no English translations exist. The high points of Retzius' research will be presented, and a representation of his lesser-known pursuits described. This paper aspires to arouse reflection on Retzius' philosophy, principles, standards and sources of inspiration.
\end{abstract}

Keywords: anatomist; Gustaf Retzius; history; nervous system

Anatomy 2016;10(1):78-84 @2016 Turkish Society of Anatomy and Clinical Anatomy (TSACA)

Gustaf Retzius, anatomist, researcher, a man of diligence, tenacity, consistency and curiosity, also a traveler, writer, poet and artist: courteous, cordial and generous (Figure 1) ${ }^{[1]}$ We trust that contemplation on some of his life episodes, his broad interests, enterprising projects, and references to Retzius by others, will shed light on his life philosophy, his priorities, his wisdom and his relationships with his wife, family, colleagues and friends.

Exploring the nature of his prodigious accomplishments generates wonder and admiration for his energy, proficiency and dedication to the finest detail. His research interests, and his publications both scientific and literary, cover an incredible range of subjects, that are often described and cited in the literature. ${ }^{[2,3]}$ Those publications that are extraordinary, and others of unanticipated content will be referred to in this article. At the close of this text we are sure that Retzius will emerge beyond his preeminence as an anatomist and researcher.

Two important creations comprise the prominent high points among his monumental publications: with Axel Key, "Studien in der Anatomie des Nervensystems und des

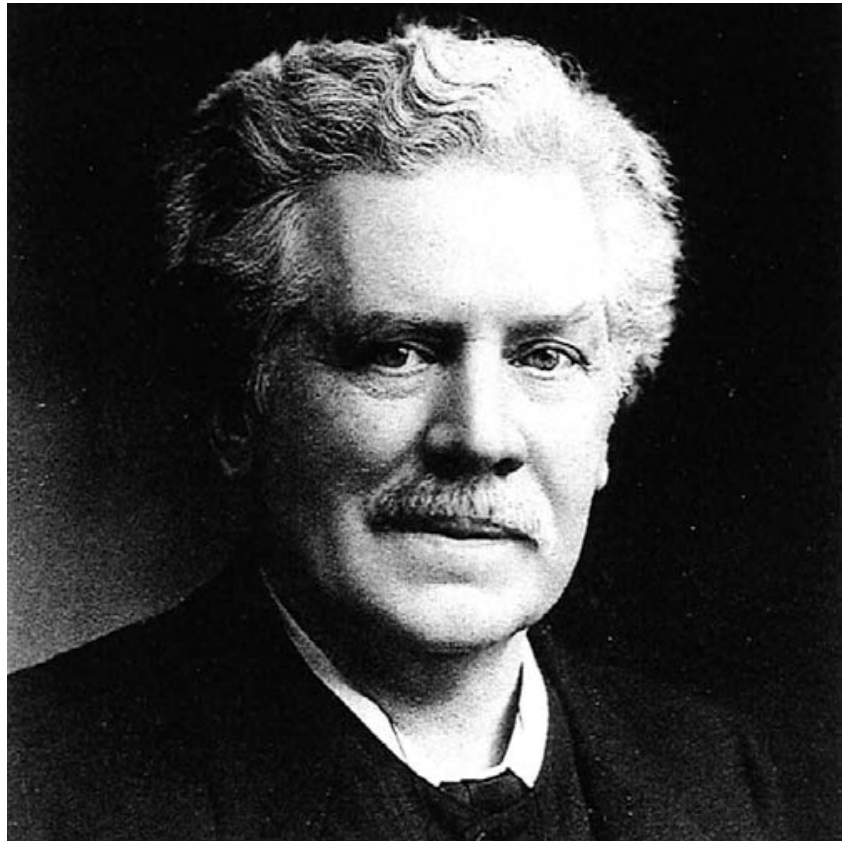

Figure 1. Magnus Gustaf Retzius. Photograph by Elliott and Fry, 1908."1] 
Bindegewebes" ${ }^{[4]}$ (Studies in the Anatomy of the Central Nervous System and Connective Tissue [arachnoidea]) 1876, and 2 volumes dedicated to the hearing organ: "Die Gestalt des membranösen Gehörorgans des Menschen" (The Structure of the Human Membranous Hearing Organ) and "Das Gehörorgan der Wirbeltiere" (The Hearing Organ of Vertebrate Animals - a comparative anatomy of the ear ) 1881-1884. ${ }^{[5,6]}$ Even today, these richly bound volumes are praised for their accuracy and valuable influence on microneurosurgery and otorhinolaryngology, respectively. Each is considered a masterpiece. For microneurosurgery, it is essential to understand the intricate arachnoid pathways in order to perform transcisternal approaches to lesions in the brain, because following these natural pathways, normal brain tissue is preserved. ${ }^{[7,8]}$

In 1869, Retzius became assistant in pathological anatomy under Axel Key, at the Karolinska Institute. Axel Key, ten years Retzius' senior, introduced cellular pathology and other modern theories and methods into anatomic and physiologic research. Scientists, liberal politicians and artists were among his friends. Teaching and research were his passion. This was evident in his commitment, loyalty, concern and deep involvement with his students. Retzius had a great affection and regard for Key, and their friendship matured into a long and productive collaboration. $^{[9-11]}$

Together Retzius and Key began the study of the cerebrospinal fluid organ on cadavers, injecting fluids dyed with methylene blue and chromium silver into subdural and subarachnoid spaces to map connections between the pathways of craniospinal fluid and the central nervous system. These investigations produced such favorable findings, the decision was reached to further advance the research, a project that continued until 1876, culminating in the publication of "Studien in der Anatomie des Nervensystems und des Bindegewebes" in two large volumes (Figure 2). ${ }^{[4,12]}$

Their studies of the compartmental architecture of the cranio-spinal arachnoidal cisterns and their macroscopic and microscopic aspects were a first in the history of medicine. The relation of the arachnoid fiber system to the arteries and veins within the cisternal spaces was revealed. They also demonstrated that the arachnoidal cistern along the dorsal aspect of the spinal cord is separated by a thin, fenestrated septum from cervical 2 to dorsal 12. Impressive drawings and photographs of great beauty and stunning accuracy documented their discoveries (Figure 3). ${ }^{[4]}$

Key, but mainly Retzius, drew sketches and made specifications which Björkman, employed to assist, then drew in detail in preparation for the stone engravers, and for chromolithography. The presentation and printing of all

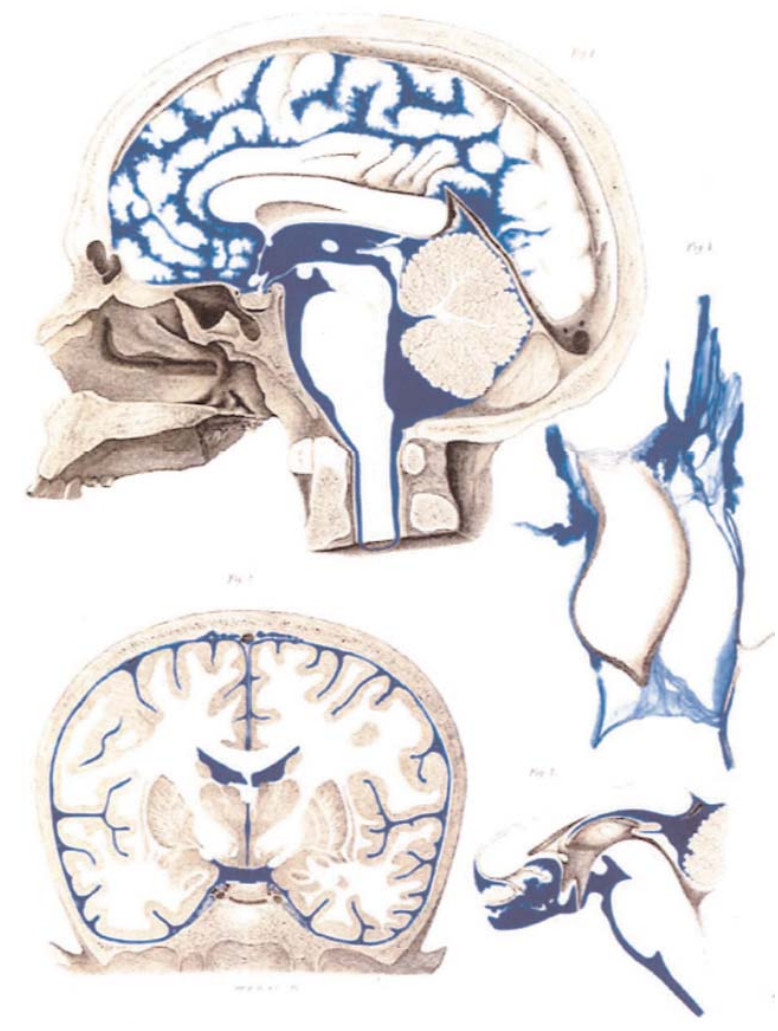

Figure 2. Injections of the subarachnoid spaces and ventricles of the brain. Retzius MG. Studien in der Anatomie des Nervensystems, Plate VII, Vol. I, 1875. ${ }^{[4]}$ [Color figure can be viewed in the online issue, which is available at www.anatomy.org.tr]

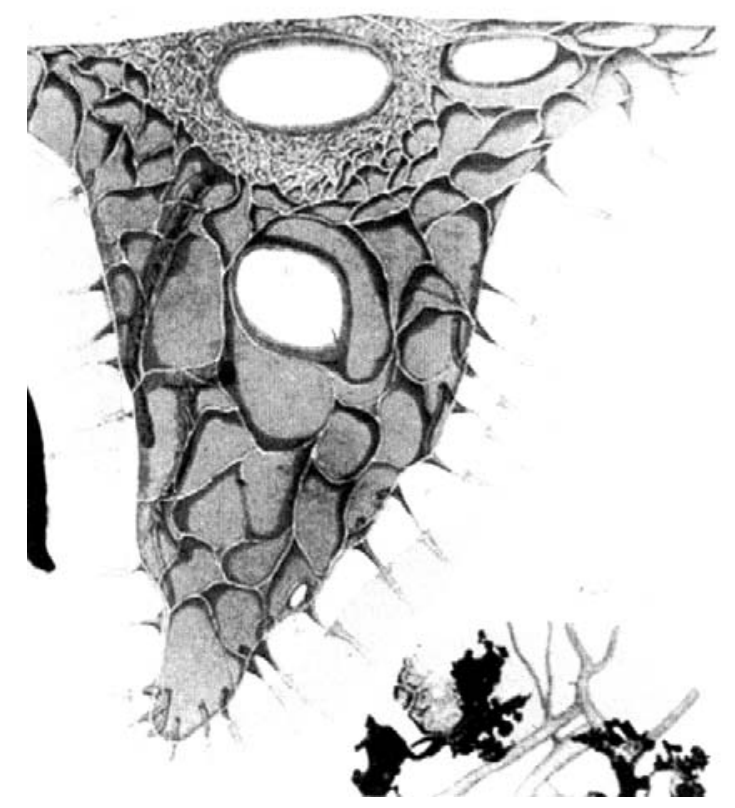

Figure 3. Arachnoid detail. Detailed microscopic study of arachnoidal architecture within a sulcus in relation to veins and arteries. Retzius MG. Studien in der Anatomie des Nervensystems, 1875. ${ }^{[4]}$ 
Rezius' publications were major considerations. He chose large folio volumes and quality paper. This proved costly, but allowed optimal imaging of the illustrations. Before Volume II could be completed, a fire in Stockholm, the greatest of that era, completely destroyed the printing house including all original manuscripts, lithograghic stones and printed plates of Volume II. Worse still, one of the prominent lithographers perished in the blaze. Retzius, an inbred optimist, swung into action to prepare a new series of slides and re-write the German text.

'Studien in der Anatomie des Nervensystems und Bindegewebes' was lauded and received with great approval both nationally and internationally. Reviews extolled admiration, and congratulatory letters flowed from colleagues abroad. The book won the prestigious Montyon Prize, awarded by the French Academy of Sciences, the equivalent of a Nobel Prize. Even today, these two volumes are of great value in the neurosciences, especially in microneurosurgery. ${ }^{[7,8]}$ The anatomic details are exquisite, and are proclaimed as refined and notable works of art. ${ }^{[13-16]}$

"Die Gestalt des Membranösen Gehörorgans des Menschen" and "Das Gehörorgan der Wirbelthiere" were colossal undertakings involving diligent observation of ears from numerous species, earnest attention to detail of illustrations that he drew himself, and altogether a strenuous proposition (Figures 4). ${ }^{[5,6]}$

Retzius possessed a keen sense of observation endowing him with the capacity to examine the most minute features of his anatomic specimens. Despite the limitations of the light microscope, available during his time, he detected details that others overlooked or failed to notice.

To prepare a perfect specimen of the inner ear is a complex procedure, in addition to the arduousness of observing the detail under the microscope and producing an accurate drawing. Retzius made refinements to his microscope technique, which resulted in remarkably sharper images that he then drew. Occasionally the findings astonished, and could not be confirmed until the advent of the electron microscope.

Checking galley proofs, Retzius was meticulous. He was particularly demanding of the lithographers and copper engraver (some copper engravings are included in the book), checking and insisting on refinement of the most subtle details. Experts today bestow glowing admiration for the accurate drawings of the ear and labyrinth. They are considered the pinnacle of his entire scientific productivity.

As was his custom, Retzius selected quality paper and binding, and a folio format for his volumes, and employed the very best lithographers and engravers. This policy resulted in two very expensive books few could afford to purchase. Without his wife's financial support, completion and publication of the hearing organ books would have been impossible. The majority of these volumes were given away to institutions and colleagues at home and abroad.

To quote Retzius: "Science is costly and seldom returns costs..... Scientific work must be seen as a sacrifice in the service of human culture". "[?]

Retzius was born into a family of acclaimed scientists. His father earned fame as an anatomist and anthropologist. His grandfather, professor of natural history, was acclaimed for his achievements in chemistry, botany, zoology, mineralogy and paleontology. His uncle on his mother's side was a botanist and entomologist. Retzius, as a child, accompanied him on excursions in the countryside, collecting specimens..$^{[9-11]}$

Retzius studied medicine in Uppsala, later Stockholm. He earned his doctorate at the University of Lund, and docent in anatomy at the Karolinska Institute. His travels during various periods as a child with his parents, and later between 1862 and 1873 to France, Germany, Belgium and Switzerland surely augmented his knowledge, expanded his scientific vista, and influenced his personality.

In 1877, a personal, extraordinary Professorship in Histology was created for him at Karolinska, and in 1889, at the age of 47, a full Professor of Anatomy.

Retzius was prodigious in his research and publications. He possessed an insatiable curiosity not only for anatomy and the sciences, but also for all the art forms in their broadest sense. We can assume that an irresistible urge drove him to write and publish in order to share with others (scientists and researchers), to educate the public, and to relate his travel and other experiences.

Between 1890 and 1914 he published, in German, 18 beautifully bound volumes, "Biologische Untersuchungen, Neue Folge" (Research in Biology, New Sequel). A golden

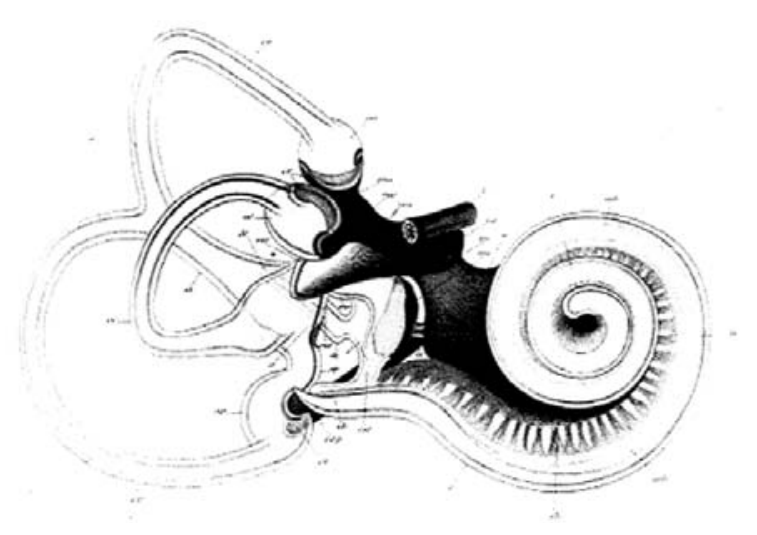

Figure 4. A drawing of the membranous labyrinth of a 6 month old human fetus showing both the vestibular and the auditory sensory receptors with innervating nerves. Retzius MG. Die Gestalt des membranösen Gehörorgans des Menschen. Stockholm: Centraltryckeriet; $1882 .{ }^{[5]}$ 


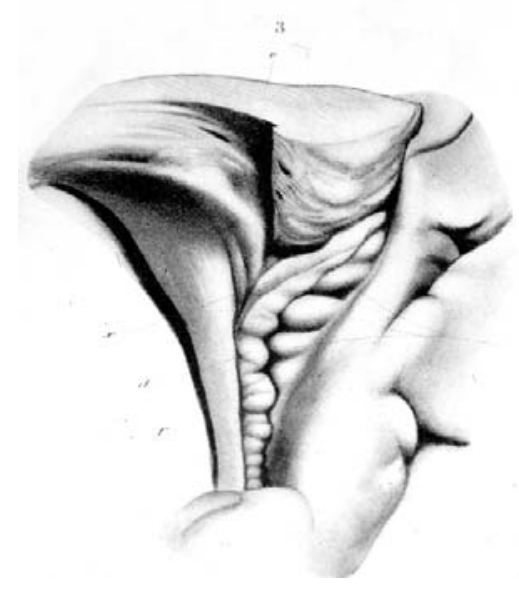

Figure 5. Superb drawing of Anders Retzius gyrus, right side. Gustaf Retzius observed these small previously unlabeled bulges, and named this structure Anders Retzius gyrus in homage to his father, famed scientist and exceptional teacher of human anatomy. ${ }^{[17]}$

frieze adorns the edges of each volume, ruby red emphasizes the gold lettering of the titles, and altogether accords the books a flavor of distinction. A 19th edition was published posthumously in 1921. Each subject was studied, investigated, and documented with clarity and attention to detail, resulting in scholarly books of superior quality: "Das Menschenhirn" ${ }^{\text {"[17] }}$ (The Human Brain, studies in macroscopic morphology, and includes the study of brains from human fetuses) 1896, "Das Affenhirn in bildliche Darstellung", ${ }^{[18]}$ (The brain of Apes-illustrated, a comparative macroscopic study of numerous brains from all ape species) 1906, and other no less impressive studies: spermatozoa, cell structure, cell division, structure of different sensory organs (e.g. eye) and macroscopic anatomy. ${ }^{[1,20]}$ Retzius was the only contributor, the editor, and usually the draughtsman, also bearer of the costs (Figures 5-7).

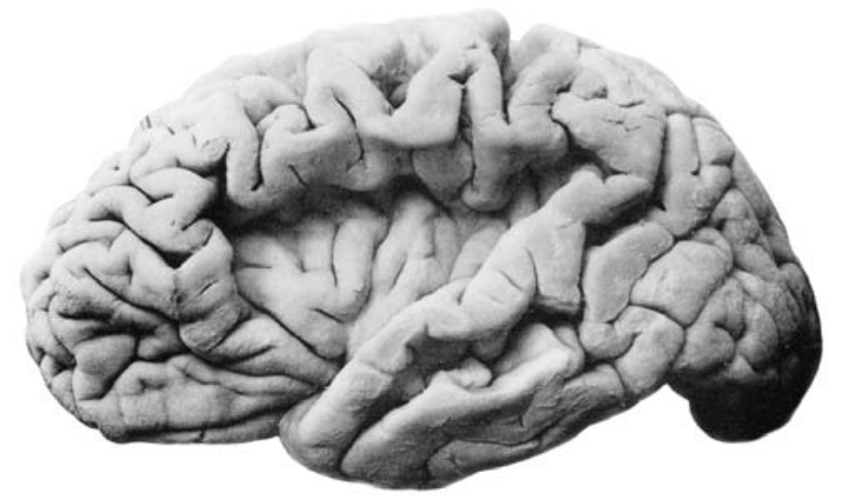

Figure 6. Outstanding photograph of the left insular region demonstrating an exceptionally precise and clear opening of the Sylvian fissure on a cadaver brain - an incredible accomplishment by Gustaf Retzius. ${ }^{[17]}$

Retzius' investigations on the microscopic structure of nerve endings, their sheaths and sensory nerve endings, in a wide variety of invertebrates and vertebrates, using his simple microscope, were valuable in creating the fundamentals for later validation of the neuron doctrine. Retzius endorsed the neuron theory, among other scientists of his time. Camille Golgi and Retzius became acquainted and corresponded from time to time. Their communications related to their research became more intense following a meeting in Stockholm, when Golgi and Ramon y Cajal were awarded the Nobel Prize in 1906 for their studies on the structure of the nervous system. ${ }^{[9]}$

From 1872, with Axel Key, pathologist, he wrote "Ur car this forsknong" which comprised popular science articles for the general public.
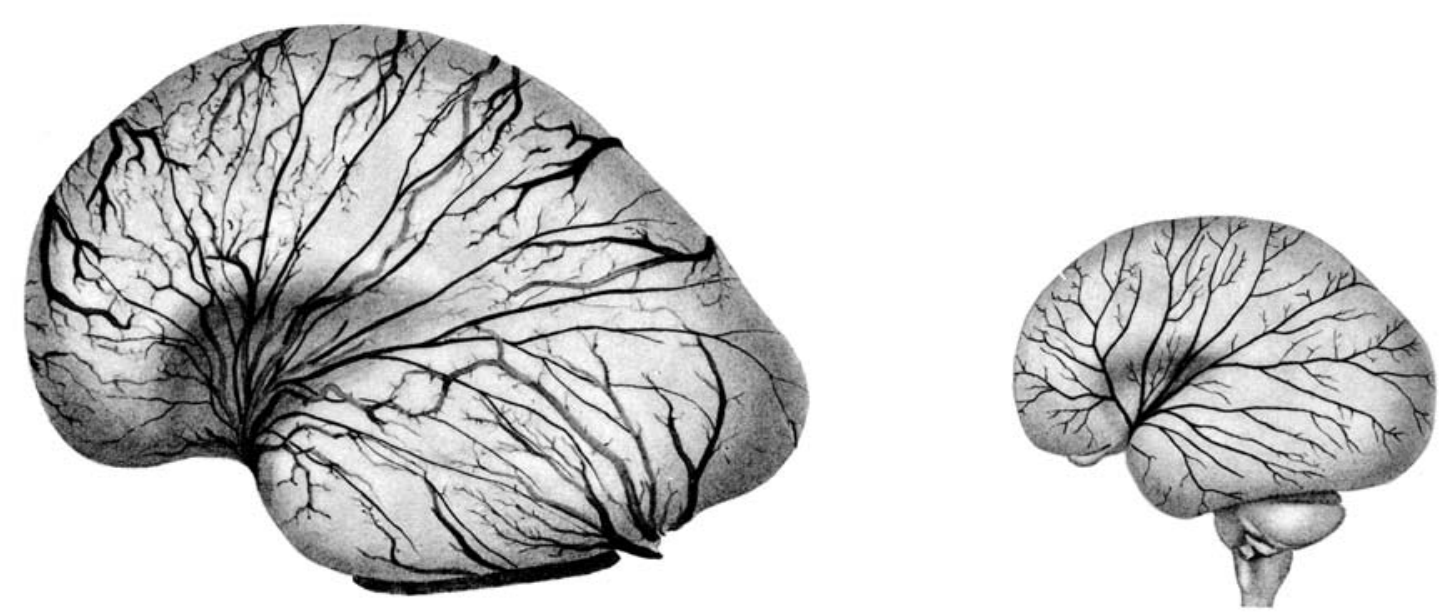

Figure 7. Radiating branches of the middle cerebral artery in an embryo cadaver brain, prepared by Retzius. ${ }^{[1]]}$ 
His writings on the natural sciences includes 127 titles; biographies (including of prominent scientists) 50 titles, travel sketches 24 titles, poems and literary translations, political essays and a variety of other literary renderings. Retzius admitted to limited discernment of music's intricate mosaic, but was inspired to compose two cantatas, both of which were performed in Stockholm.

In 1876, Retzius married Anna Wilhelmina Hierta. They became acquainted after her father, Lars Hierta, died, when she, her mother and sister approached Retzius for advice. The family was wealthy and held an eminent position in the community. Lars Hierta was a successful businessman and politician, and one of his projects was the founding of the newspaper Aftonbladet. The family's wish was to establish a memorial in the name of Lars Hierta. Retzius aspired to creating an institution similar to the Smithsonian, and readily agreed to become involved.

The friendship between Anna and Retzius blossomed and they were married in November 1876. Their honeymoon of six months was spent on the French Riviera, and in Rome, Naples, Capri, Bellagio and Venice; walking, painting, visiting museums and meeting scientists; a pleasing and delightful tour.

Anna was a very energetic lady and pursued her own projects. Before marriage she introduced handicrafts into elementary schools because she felt there should be some kind of respite from 'brain' activities. She organized after school recreation centers for children 7 to 14 years of age to prevent them roaming the streets until their parents returned home from the factories. She read foreign newspapers and translated articles on school, teaching, hygiene, cookery and handicrafts. When Retzius decided to leave his positon at Karolinska in 1890, to continue his research unhindered by student obligations and faculty commitments, through Anna, his financial security was assured.

Anna accompanied Retzius on all his travels and in 1889 they toured Egypt for three months, visiting the ancient cities. The main purpose of the journey was to later write articles for the general public, to increase knowledge of Egyptian culture and to collect specimens; brains and crania for the anatomy museum at Karolinska, and ethnographic artifacts for the ethnology department of the natural history museum. Among other items, one hundred Proto-Egyptian crania, at 3 piastras each, were carefully packed into crates at their hotel in Luxor. On almost every trip Retzius collected. On one excursion he even packed his microscope. In Cairo, the couple wished to experience the nightlife. Their dragoman escorted them to a café where they became enthralled by the story- teller and the magical and focused demeanors of the listeners. They stayed long, even though they understood not a word.

Following intense preparations for the hearing organ books, Retzius was advised to suspend his research for a while, although he continued to teach histology. In 1884, during this period of rest, Anna and Retzius purchased the newspaper Aftonbladet, founded by Anna's father. The circulation had declined and Retzius launched into improving the content, boosting the image of the newspaper and increasing circulation. He was the editor and wrote articles on a variety of topics, themes and affairs of interest.

During these years at Aftonbladet 1884 to 1907, Retzius maintained his interest in the developments in neuroanatomy, and undertook research in the field. Thus, in 1888 the Stockholm Biological Society was formed with the purpose of publishing results and meeting regularly. The journal, "Biologiska Föreningens Förhandlingar" (The Transactions of the Biological Society), was financed by Retzius, and distributed in Sweden and abroad. Many of the papers were in German. Retzius, ever dynamic, was the most frequent lecturer at meetings, and the most prolific writer for the journal. After four years it was discontinued.

In 1872 Retzius, with the assistance of his sister Elisabet (Betty), published translations of some of the poems by the Scottish poet Robert Burns. Retzius translated various publications into Swedish, and Burns, at first, appears an out-of-the-ordinary choice, because many of Burns' poems are written in the Lallans or Lowland Scots dialect of Ayrshire, and are written down just as people spoke. In any language other than this dialect, the 'music' and rhythm of Burns' poems and songs are lost. Nonetheless, Burns has been translated into many languages, no doubt due to his themes of brotherhood, love and loss, distaste for hypocrisy and cant, and aversion for class system, and because of his candid and uncomplicated language. It is reasonable to presume that all of these aspects which are intertwined in Burns' writings, and which reveal his life philosophy, appealed to Retzius. ${ }^{[21]}$

Another episode of note, exemplifying Retzius' principles, concerns August Strindberg. Feminism, equal rights for women, the church, religion and morals were topics debated intensely at this time, especially during the 1880s. Strindberg had published a collection of short stories on these themes, "Giftas" (Married), for which he was accused of blasphemy and was tried in Stockholm. Retzius, as editor of Aftonbladet, wrote a stirring editorial the day before the trial titled "En Samvetssak" (A Matter of Conscience), 
expounding and disparaging the antique dogmas of the church. According to general opinion, the editorial was instrumental in securing Strindberg's acquittal. A shy Strindberg appeared unannounced at the Aftonbladet office to convey his thanks to Retzius. Interesting to note that Anna, Retzius' wife, was very conservative and moralistic in her views. In discussions revolving around the emancipation of women, feminism and morals with friends and colleagues at their home and elsewhere, Retzius openly supported his wife. ${ }^{[9]}$

Retzius has been described as courteous, gracious and generous, an idealist and a humanitarian. He and his wife were very hospitable, often inviting to their home. Retzius much appreciated his helpers, assistants, and technicians.

As mentioned previously, he presented copies of "Studien in der Anatomie des Nervensystems und des Bindegewebes," and "Menchliches Gehörorgan" to colleagues at home and abroad. He donated money to many good causes, and also purchased items for his department, even during the time before marriage, when his salary was little.

Following the great fire in Stockholm in 1876, where at the printers all manuscripts and illustrations of Volume II were destroyed, Anna offered Retzius sympathy for this loss. Retzius is said to have replied, "What is that, compared to the human lives that have been lost in this terrible fire." This left an enduring, favorable impression on Anna, who already held him in high regard for his reserved yet strong character. ${ }^{[0]}$

Following the Huxley lecture in London, Professor Keith, celebrated anthropologist, noted, "No fellow of the Institute who had the fortune to listen to the Huxley Lecture of 1909 can forget the graciousness, courtesy, and modesty of the lecturer, nor the pleasant memories which his wife and he left with his audience." Further Keith wrote, "He did more to enrich the literature of physical anthropology, anatomy, and physiology than any other man of his time. His numerous monographs deserve to be called princely, whether we consider the finish, the magnificence of their illustrations, their full and accurate record of observation, or the exactness of the methods which were employed in their production."

In 1892, at the request of the editor of a series of short sketches describing the leading men of Sweden, Retzius wrote a profound and revealing epistle referring to his growth as a person, and the influences in his career development. To conclude our brief celebration devoted to Gustaf Retzius, a short excerpt is quoted here: "But there was also something else which made an impression on my young mind. My father worked not alone with books and desk. "Search first and read afterward" was one of his principles. He opened always first nature's book before be turned to the book-shelf. ${ }^{\text {"[10] }}$

\section{Acknowledgements}

The authors thank David Murray R. N. for his guidance on Robert Burns.

\section{References}

1. Wikimedia Commons. Magnus Gustav Retzius. Photograph by Elliott \& Fry, 1908 [Internet]. St. Petersburg (FL): Wikimedia Foundation, Inc.; c2001 [cited 2016 Jan 23]. Available from: https://commons.wikimedia.org/wiki/File:Magnus_Gustav_Retzius. _Photograph_by_Elliott_\%26_Fry,_1908._Wellcome_L0013126. jpg/.

2. Sullivan WE, Mortensen OA. Visualization of the movement of a brominized oil along peripheral nerves. Anat Rec 1934;59:493-501.

3. Bassi G. Discovery of the brain lymphatic system [Internet]. [posted 2015 Jun 30; cited 2016 Jan 23]. Available from: http://brainimmune.com/the-discovery-of-the-brain-lymphatic-system/.

4. Key A, Retzius, G. Studien in der Anatomie des Nervensystems und des Bindegewebes. Stockholm: Samson Wallin; 1875.

5. Retzius MG. Die Gestalt des membranösen Gehörorgans des Menschen. Stockholm: Centraltryckeriet; 1882.

6. Retzius MG. Das Gehörorgan der Wirbelthiere. Morphologischhistologische Studien. Band I. Das Gehörorgan der Fische und Amphibien. Band II. Das Gehörorgan der Reptilien, der Vögel und der Säugethiere. Stockholm: Samson Wallin; 1881-1884.

7. Yaşargil MG. Microneurosurgery. Vol. I. Stuttgart: Thieme; 1984. p. 5-23.

8. Yaşargil MG. Microneurosurgery. Vol. IVB. Stuttgart: Thieme; 1996. p. 74-6.

9. Lindblad T. Gustaf Retzius. A biography. Stockholm: Hagströme; 2007.

10. Larsell O. Gustaf Retzius 1842-1919. The Scientific Monthly $1920 ; 10: 558-69$.

11. encyclopedia.com: Retzius, Magnus Gustaf [Internet]. New York (NY): Charles Scribner's Sons; 2008 [cited 2016 Jan 23]. Available from: http://www.encyclopedia.com/doc/1G2-2830903634.html/.

12. hagstromerlibrary.ki.se: Retzius, (1842-1919) \& Key, Axel (1832-1901). Studien in der Anatomie des Nervensystems und des Bindegewebes. Erste Hälfte und zweite Hälfte: erste und zweite Abtheilung. Stockholm, Norstedt \& Söner, 1875-1876, 1903 [Internet]. Stockholm: Hagströmer Medico-Historical Library, Karolinska Institutet; [cited 2016 Jan 23]. Available from: https://hagstromerlibrary.ki.se/books/292/.

13. viaLibri.net: Studien in der Anatomie des Nervensystems und des Bindegewebes. Key, Axel \& Gustaf Retzius - 1875 [Internet]. Cambridge (UK): viaLibri; c2016 [updated 2012 Feb 8; cited 2016 Jan 23]. Available from: https://www.vialibri.net/item_pg_i/2565651875-key-axel-gustaf-retzius-studien-der-anatomie-des-nervensystems-und.htm/.

14. A conversation between Mihnea Mircan and Erika Hock [Internet]. [cited 2016 Jan 23]. Available from: http://www.erikahock.de/mircan_hock.html/.

15. christies.com: Key, Axel (1832-1901) and Magnus Gustaf Retzius (1842-1919). Studien in der Anatomie des Nervensystems und des Bindegewebes. Stockholm: Samson \& Wallin, P. A. Norstedt \& Söner, 1875-76. 1876 [Internet]. [place unknown]: Christie's; c2016 [cited 2016 Jan 23]. Available from: http://www.christies.com/ lotfinder/books-manuscripts/key-axel-and-magnus-gustaf-retzius- 
4960059-details.aspx? from=salesummary\&intObjectID $=4960059 \&$ sid=6fdbeac1-6df7-4fc3-8a39-24d47c8e2234/.

16. catawiki.com: Anatomy; Axel Key \& Gustaf Retzius - Studien in der Anatomie des Nervensystems und des Bindegewebes - 2 Vols. 1875/1876 [Internet]. [place unknown]: Catawiki; c2016 [cited 2016 Jan 23]. Available from: http://auction.catawiki.com/kavels/2069463anatomy-axel-key-gustaf-retzius-studien-in-der-anatomie-desnervensystems-und-des-bindegewebes-2-vols-1875-1876/.

17. Retzius MG. Das Menschenhirn. Studien in der makroskopischen Morphologie. Band I-II. Stockholm: Nordstedt; 1896.

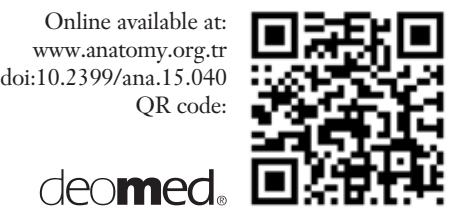

18. Retzius MG. Das Affenhirn in bildlicher Darstellung. Jena: Gustav Fischer; 1906

19. Retzius MG. Notiz über die Windungen an der unteren Fläche des Splenium corporis callosi beim Menschen und bei Tieren. Arch Anat Physiol Anat Abthlg 1877;474-9.

20. Retzius MG. Zur Morphologie der Fascia dentata und ihrer Umgebung. Biologische Untersuchungen 1898;8:49-58.

21. Burns R. My heart is sair [Internet]. [updated 2014 Jul 28; cited 2016 Jan 23]. Available from: http://www.lieder.net/lieder/get_ text.html? TextId=19531/.

Correspondence to: M. Gazi Yaşargil, MD

Department of Neurosurgery, School of Medicine,

Yeditepe University, Istanbul, Turkey

Phone: +90216578 4272

e-mail: dianne9182@gmail.com

Conflict of interest statement: No conflicts declared.

This is an open access article distributed under the terms of the Creative Commons Attribution-NonCommercial-NoDerivs 3.0 Unported (CC BY-NCND3.0) Licence (http://creativecommons.org/licenses/by-nc-nd/3.0/) which permits unrestricted noncommercial use, distribution, and reproduction in any medium, provided the original work is properly cited. Please cite this article as: Yaşargil MG, Yaşargil DCH. Gustaf Retzius - a glimpse into his lifetime achievements and into the fabric of his character. Anatomy 2016;10(1):78-84. 